\title{
Metoda PNF w odniesieniu do wytycznych Society on Scoliosis Orthopaedic and Rehabilitation Treatment (SOSORT) dotyczących leczenia zachowawczego osób ze skoliozami
}

\section{PNF method in relation to the guidelines of Society on Scoliosis Orthopaedic and Rehabilitation Treatment (SOSORT) for conservative treatment of people with scoliosis}

Agnieszka Stępień ${ }^{1}, \mathrm{Krzysztof} \mathrm{Graff',} \mathrm{Anna} \mathrm{Kloze}^{1}$, Jolanta Stępowska', Jakub Marciński

${ }^{1}$ Akademia Wychowania Fizycznego Józefa Piłsudskiego, Wydział Rehabilitacji, Katedra Rehabilitacji, Warszawa

${ }^{2}$ Centrum Rehabilitacji Funkcjonalnej ORTHOS, Warszawa

Streszczenie

Wstęp: Society on Scoliosis Orthopaedic and Rehabilitation Treatment (SOSORT) jest międzynarodową organizacją wyznaczającą standardy leczenia osób ze skoliozami i prowadzenia badań naukowych w tej dziedzinie. Standardy leczenia uwzględniają konieczność stosowania fizjoterapii. Wytyczne SOSORT określają jakie warunki powinny spełniać metody fizjoterapii stosowane w procesie leczenia. Jedną z koncepcji stosowanych na świecie w procesie leczenia zachowawczego osób ze skoliozą jest metoda Proprioceptive Neuromuscular Facilitation (PNF). International PNF Association (IPNFA) tworzy standardy nauczania, stosowania metody PNF i prowadzenia badań naukowych związanych z koncepcją.

Cel: Celem pracy jest próba wykazania zgodności założeń metody PNF z wytycznymi SOSORT dotyczącymi leczenia zachowawczego skolioz.

Materiat $i$ metody: Do analizy wykorzystano rekomendacje SOSORT stworzone w latach 2005 - 2012 oraz informacje i wiedzę zgodną z aktualnymi ustaleniami International PNF Association (IPNFA).

Wyniki: W pracy wykazano zgodność założeń metody PNF z wytycznymi SOSORT odnoszącymi się do fizjoterapii takimi jak: indywidualne planowanie leczenia, ukierunkowanie na główne cele leczenia (zatrzymanie progresji skrzywienia, poprawa funkcji układu oddechowego, zmniejszenie dolegliwości bólowych, względy estetyczne) oraz możliwość specjalistycznego oddziaływania na deformacje kręgosłupa (autokorekcja kręgosłupa i miednicy w trzech płaszczyznach, stabilizacja postawy, trening czynności codziennych, edukacja zdrowotna). Wstępne badania wykazują pozytywny wpływ wybranych wzorców metody PNF na parametry posturalne osób ze skoliozą.

Wnioski: Szczegółowo opisana struktura metody PNF może być wykorzystana przy planowaniu badań naukowych. Konieczne jest prowadzenie badań mających na celu wykazanie skuteczności metody PNF w procesie leczenia osób ze skoliozą.

Słowa kluczowe: skolioza, fizjoterapia, metody, wytyczne, PNF 


\section{Abstract}

Introduction: Society on Scoliosis Orthopaedic and Rehabilitation Treatment (SOSORT) is an international organization which determines standards for scoliosis treatment and research. Physiotherapy is a necessary part of treatment standards. SOSORT indicates which conditions must be fulfilled by physiotherapy methods in order to be used for scoliosis treatment. One of the concepts used worldwide in the process of scoliosis conservative treatment is Proprioceptive Neuromuscular Facilitation(PNF). International PNF Association (IPNFA) establishes the PNF teaching standards, application and related research.

Aim: The goal of this work is to demonstrate conformity PNF method to SOSORT guidelines for conservative treatment of people with scoliosis.

Material and methods: SOSORT recommendations set in 2005-2012 were used to analyze knowledge and information, according to the newest IPNFA agreements.

Results: Conformity PNF method to SOSORT guidelines can be observed in: personal treatment planning; focus on treatment goals (stopping the progression of curvature, breathing function improvement, reduction in pain, aesthetic issues), possibility of special effects on the spine deformity (autocorrection of the spine and pelvis in three planes, stabilization of the posture, activities of the daily living and general health education). The positive influence of the selected PNF patterns on postural parameters of individuals with scoliosis was observed in the initial studies.

Conclusions: Described in details structure of PNF method can be used in the planning of research. It is necessary to conduct research to demonstrate the effectiveness of PNF method in the treatment of people with scoliosis.

\section{Key words:}

\section{scoliosis, physiotherapy, methods, guidelines, PNF}

\section{Wstęp}

Society on Scoliosis Orthopaedic and Rehabilitation Treatment (SOSORT) jest organizacją międzynarodową zrzeszającą specjalistów różnych zawodów medycznych lub związanych z medycyną (lekarze, fizjoterapeuci, psycholodzy, ortotycy), skupionych na problemach zdrowotnych osób, u których rozpoznano skoliozę. Jednym z zadań Towarzystwa jest tworzenie standardów, które będą sprzyjać większej skuteczności leczenia osób ze skoliozami oraz rozwojowi badań naukowych.

Skolioza jest definiowana jako trójpłaszczyznowa deformacja kręgosłupa i tułowia [1] charakteryzująca się wygięciem bocznym w płaszczyźnie czołowej, nieprawidłowym ukształtowaniem krzywizn w płaszczyźnie strzałkowej oraz rotacją i torsją kręgów w płaszczyźnie poprzecznej. Nieleczona skolioza prowadzi do deformacji i kompensacji w innych częściach narządu ruchu, narastania dolegliwości bólowych, zmniejszenia ogólnej sprawności i wydolności organizmu. Scoliosis Research Society (SRS) oraz SOSORT zalecają by skoliozę rozpoznawać przy kącie skrzywienia minimum 10 stopni wg Cobba. Częstość występowania takich skolioz szacuje się na 2-3\% [2]. Największą grupę skolioz (ponad 80\%) stanowią skoliozy idiopatyczne. One właśnie stają się tematem zainteresowania specjalistów zaangażowanych w proces leczenia. Od wielu lat prowadzone są badania, których celem jest opracowanie skutecznych sposobów leczenia deformacji kręgosłupa. Leczenie skoliozy zależy od wielu czynników takich jak wielkość skrzywienia, wiek dziecka, tempo progresji oraz typ deformacji.

Fizjoterapia została uznana za jedną z istotnych składowych procesu leczenia osób ze skoliozą. W piśmiennictwie pojawiły się przykłady efektywnego zastosowania fizjoterapii w leczeniu zachowawczym skolioz $[3,4]$. Obecne standardy leczenia zalecają w początkowej fazie stosowanie fizjoterapii w warunkach ambulatoryjnych [5]. W przypadku braku poprawy zaleca się, by w drugim etapie leczenia objąć dziecko ze skoliozą intensywną fizjoterapią w warunkach stacjonarnych. W trzecim etapie uzupełnieniem fizjoterapii jest zastosowanie gorsetu [6].

Według zaleceń SOSORT metody fizjoterapii stosowane $\mathrm{w}$ leczeniu zachowawczym skolioz powinny być zgodne z opracowanymi wytycznymi, a ich efektywność należy wykazać w badaniach naukowych. Na świecie stosuje się wiele koncepcji leczenia zachowawczego skolioz, ale tylko kilka z nich doczekało się potwierdzenia skuteczności [4,7]. Zalicza się do nich metodę Lyon [8], Side-Shift [9,10], metodę DoboMed [11], Schroth $[12,13]$, SEAS [14], MedX [15] i kilka innych.

Jedną z koncepcji stosowanych w terapii osób ze skoliozami jest metoda Prioprioceptive Neuromuscular Facilitaction (PNF). Od kilkudziesięciu lat jest ona powszechnie stosowana na świecie $\mathrm{w}$ terapii osób z dys- 
funkcjami układu nerwowego, zaburzeniami w obrębie narządu ruchu oraz w pediatrii [16-18]. Podstawą planowania terapii $\mathrm{z}$ wykorzystaniem metody PNF jest Międzynarodowa Klasyfikacja Funkcjonowania, Niepełnosprawności i Zdrowia (International Classification of Functioning, Disability and Health - ICF) [19], opracowana przez Światową Organizację Zdrowia (WHO). Określa ona płaszczyznę do oceny zdrowia i sprawności człowieka na poziomie struktur i funkcji ciała, aktywności oraz uczestniczenia w codziennych sytuacjach życiowych. Metoda PNF posiada swoje oryginalne podstawy, zawiera zasady główne, techniki, wzorce głowy, łopatek, miednicy, kończyn górnych i dolnych oraz wzorce tułowia. Techniki i wzorce są dokładnie opisane. Każdy ruch wykonywany podczas kinezyterapii posiada swoją nazwę, co pozwala na precyzyjne opisanie i dokumentowanie podejmowanych działań [16]. Podstawą badania oraz planowania kinezyterapii zgodnie z metodą PNF jest umiejętność analizy jakości i sekwencji ruchów wykonywanych przez człowieka, opisanie związków między nimi i określenie ich wpływu na narząd ruchu. Nowsze koncepcje fizjoterapii, w tym metody fizjoterapii skolioz, wykorzystują elementy metody PNF. We wstępnych badaniach wykazano pozytywny wpływ wybranych wzorców metody PNF na parametry posturalne osób ze skoliozą [20].

Celem pracy jest próba wykazania zgodności założeń metody PNF z wytycznymi SOSORT dotyczącymi leczenia zachowawczego skolioz.

\section{Materiał i metody}

Do analizy wykorzystano zalecenia SOSORT stworzone w latach 2005 - 2012 oraz informacje i wiedzę zgodną z aktualnymi ustaleniami International PNF Association (IPNFA). IPNFA od 1990 roku odpowiada za tworzenie jednolitych standardów nauczania i stosowania metody PNF na całym świecie oraz wspieranie badań naukowych związanych z rozwojem koncepcji.

\section{Wyniki}

Grupa SOSORT w ostatnich latach opracowała wiele znaczących wytycznych porządkujących system działań w procesie leczenia osób ze skoliozą. Część rekomendacji dotyczy postępowania fizjoterapeutycznego. Najważniejsze z nich przedstawiono poniżej.

\section{Indywidualne podejście do osoby ze skoliozą, współpraca zespołu specjalistów}

W opinii specjalistów SOSORT leczenie osoby ze skoliozą powinno być planowane indywidualnie na podstawie wywiadu i naturalnego przebiegu choroby [6]. W proces leczenia musi być zaangażowany zespół specjalistów (le- karz, fizjoterapeuta, ortotyk), którzy ze sobą współpracują [21] w celu uzyskania najlepszego, indywidualnego efektu. SOSORT zaleca by metody specjalistyczne fizjoterapii stosowane w leczeniu zachowawczym skolioz były stosowane przez wykwalifikowanych specjalistów, którzy przeszli odpowiednią edukację [6,22].

Jednym z podstawowych założeń metody PNF jest indywidualne podejście do pacjenta i zgłaszanych przez niego problemów. Wywiad zawiera pytania odnośnie czasu i okoliczności rozpoznania skoliozy oraz oczekiwań dziecka lub jego rodziny odnośnie codziennego funkcjonowania. Dzieci i ich opiekunowie najczęściej pytają o możliwość korekcji skrzywienia oraz kontynuowania ulubionych zajęć (taniec, gra na instrumencie) lub uprawiania dyscypliny sportowej (pływanie, gra w tenisa, siatkówka, koszykówka). Niejednokrotnie zgłaszają, iż największym problemem są dolegliwości bólowe. Planowane postępowanie fizjoterapeutyczne ukierunkowane jest na poprawę funkcji zmienionych struktur ciała, zmianę niekorzystnych nawyków ruchowych podczas codziennych czynności w domu i szkole oraz hobby. Taka strategia jest także zgodna z opinią grupy SOSORT wskazującą na pozytywny wpływ ruchu (sport, lekcje wychowania fizycznego) na ogólną wydolność i inne cechy sprawności psychoruchowej dzieci ze skoliozą.

Fizjoterapeuci posługujący się metodą PNF mają świadomość jak ważne w leczeniu jest działanie zespołowe [21] i dlatego ściśle współpracują z innymi specjalistami zaangażowanymi w proces leczenia. Metoda jest stosowana przez osoby, które uczestniczyły w specjalistycznych szkoleniach metody PNF. Fizjoterapeuci, którzy ukończyli przynajmniej moduł podstawowy moga wziąć udział w szkoleniu, które poświęcone jest leczeniu zachowawczemu skolioz zgodnie z zasadami PNF, wytycznymi międzynarodowymi oraz aktualną wiedzą medyczną.

\section{Cele leczenia zachowawczego}

W 2005 roku grupa SOSORT opracowała wytyczne i wskazania do zachowawczego leczenia skolioz. Wyróżniono morfologiczne i funkcjonalne jego cele. Ważnym aspektem jest uzyskanie pozytywnej samooceny pacjenta i dobrej jakości jego życia.

Za główne cele leczenia zachowawczego uznano:

1) zatrzymanie progresji skrzywienia,

2) poprawę funkcji układu oddechowego,

3) zmniejszenie dolegliwości bólowych,

4) względy estetyczne - poprawa wyglądu. Korekcja ustawienia ciała ma wpływ na samoakceptację i podnosi jakość życia pacjentów ze skoliozą [6,7].

Podstawą do określenia indywidualnego sposobu postępowania $\mathrm{w}$ ramach metody PNF mającego na celu zatrzymanie progresji skrzywienia jest określenie typu deformacji oraz ocena zmian funkcjonalnych w układzie 
narządu ruchu. Badanie osoby ze skoliozą nie odbiega od ogólnie przyjętych zasad. Obejmuje ocenę ustawienia kręgosłupa w płaszczyźnie czołowej, strzałkowej i poprzecznej. Istotną częścią badania jest ocena osiowego położenia kręgosłupa, analiza ustawienia łopatek i miednicy, pomiar kąta rotacji tułowia w pozycji stojącej i siedzącej, ocena ruchomości poszczególnych stawów oraz długości kończyn dolnych [23]. Działania podejmowane w trakcie terapii mają na celu odwracanie procesu deformacji i zmianę zaburzonej biomechaniki w narządzie ruchu.

Metoda PNF zakłada konieczność przygotowania osoby leczonej do właściwego wykonywania zadań ruchowych w codziennej rzeczywistości. W związku z tym zaleca się by poświecić chwilę uwagi na obserwację ustawienia ciała podczas ruchów w pozycji siedzącej, stojącej, w poszczególnych fazach chodu oraz zapytać o zainteresowania / hobby. W przypadku uprawiania sportu lub wykonywania innego hobby związanego z wymuszonym ustawieniem ciała należy przeanalizować kolejność i jakość wykonywanych ruchów.

Stymulacja oddychania jest jedną ze składowych metody PNF wykorzystywanych w wielu przypadkach klinicznych. Prowadzi się ją w różnych pozycjach ciała. Celem terapii oddechowej wg metody PNF jest pobudzenie mięśni oddechowych, zwiększenie ruchomości i korekcja ustawienia kręgosłupa i żeber, stymulacja symetrycznych ruchów klatki piersiowej, poprawa kontroli posturalnej, przywrócenie prawidłowego wzorca oddychania podczas czynności dnia codziennego. Stymulację oddychania prowadzi się także u osób, którym zalecono noszenie gorsetu. Celem jest zapobieganie dysfunkcji oddechowej i narastaniu ograniczenia ruchomości klatki piersiowej. W czasie terapii zwykle stosuje się opór manualny i stretch (szybkie rozciągnięcie zespołu mięśni wdechowych stosowane tuż przed wdechem lub w czasie wdechu) zaliczane do zasad głównych. Wykorzystuje się również ćwiczenia oddechowe torem górno - żebrowym / mostkowym, dolno - żebrowym oraz brzusznym (przeponowym). Dobór toru oddechowego zależy od rodzaju deformacji klatki piersiowej i ograniczeń ruchowych w stawach międzykręgowych i stawach żebrowo - kręgowych. Na uwagę zasługuje torowanie oddychania torem brzusznym, gdyż u wielu osób ze skoliozą dochodzi do jednostronnego ograniczenia ruchów przepony i wtórnych dolegliwości bólowych.

PNF dysponuje wieloma środkami mechanicznymi, które znajdują zastosowanie u pacjentów zgłaszających dolegliwości bólowe. Terapia poprzedzona jest dokładnym wywiadem oraz badaniem. Ruchy prowadzi się do granicy bólu, często wykorzystując działania pośrednie, z daleka od miejsca odczuwanych dolegliwości. W celu zmniejszenia dolegliwości bólowych wykorzystuje się techniki rozluźniające ,, Trzymaj - Rozluźnij” oraz „Na- pnij - Rozluźnij”. Technika „Rytmiczna Stabilizacja” służy do stabilizacji w nowej pozycji ciała. Naprzemienne izometryczne skurcze mięśni uzyskiwane podczas wykonywania tej techniki często przynoszą efekt wtórnego rozluźnienia napiętych mięśni.

Korekcja trójpłaszczyznowa zwykle przynosi poprawę wyglądu i podnosi samoocenę osoby uczestniczącej w terapii.

\section{Fizjoterapia - specjalistyczne oddziaływania}

Wg wytycznych SOSORT [22, 24] fizjoterapia nie powinna wykorzystywać ćwiczeń ogólnych, ale specjalne oddziaływania przeznaczone dla poszczególnych deformacji kręgosłupa. Zaleca się by terapia ruchowa była ukierunkowana na:

1) nauczanie umiejętności autokorekcji kręgosłupa i miednicy w trzech płaszczyznach,

2) stabilizację prawidłowej postawy,

3) trening czynności codziennych $z$ uwzględnieniem skorygowanego ustawienia ciała,

4) edukację zdrowotną pacjenta i jego rodziny.

Metoda PNF spełnia wszystkie wymienione założenia. Edukację pacjenta i jego rodziny prowadzi się od początku terapii. Pierwsze spotkanie ma na celu uświadomienie osobie poddawanej terapii $\mathrm{z}$ jaką deformacją mamy do czynienia i jakie kompensacje powoduje ona w narządzie ruchu. Edukacja osoby ze skoliozą i jego bliskich jest warunkiem przystąpienia do nauczania autokorekcji oraz treningu stabilizacji.

Autokorekcję zalecaną przez SOSORT można uznać za pierwszą fazę kontroli motorycznej koncepcji PNF. Wyróżnia się cztery podstawowe fazy kontroli motorycznej:

1) mobilność - definiowana jako umiejętność przyjmowania prawidłowej pozycji ciała (autokorekcja). Nauczanie autokorekcji odbywa się w oparciu o podstawowe zasady główne (np. stymulacja dotykowa, stymulacja słuchowa, stymulacja wzrokowa, opór manualny, wzorce ruchowe, aproksymacja) oraz techniki (Technika Odtwarzanie). Autokorekcja wykonywana jest w różnych pozycjach ciała (leżącej, siedzącej, stojącej). Mobilność w metodzie PNF może także oznaczać możliwość wykonania ruchu w pełnym zakresie. W przypadku ograniczonej mobilności (np. ograniczone zgięcie kręgosłupa w odcinku piersiowym kręgosłupa, ograniczony zakres ruchu w stawie biodrowym) utrudniającej wykonanie autokorekcji stosowane są techniki rozluźniające metody PNF: „Napnij -Rozluźnij” lub „Trzymaj Rozluźnij".

2) stabilność - umiejętność utrzymywania prawidłowego ustawienia ciała w różnych pozycjach. Dwie techniki metody PNF - „Stabilizacja Zwrotna” i ,Rytmiczna Stabilizacja” są wykorzystywane do uzyskania stabilizacji. Sposób wykonania technik (kolejność 
ruchów fizjoterapeuty, sposób układania rąk, kierunek oporu) jest ściśle określony.

3) mobilność na stabilności - umiejętność wykonywania ruchów w prawidłowej pozycji ciała (np. picie, pisanie w prawidłowej pozycji siedzącej). Większość czynności wykonywanych w życiu wymaga ruchów kończyn górnych i dolnych. Każdy ruch kończyny górnej i dolnej poprzedzony jest napięciem mięśni tułowia (mięśni stabilizujących łopatki, mm. odpowiedzialnych za stabilizację odcinka lędźwiowego kręgosłupa)). Dlatego tak ważne jest przygotowanie kontroli mięśni proksymalnych, które ma miejsce we wcześniejszych fazach kontroli motorycznej (mobilność, stabilność). Do treningu czynności codziennych wykonywane są wycinki wzorców kończyn górnych i dolnych metody PNF. Wykonuje się je podczas korekcji tułowia (stabilność proksymalna).

4) zręczność - zdolność do wykonywania trudnych ruchów oraz przemieszczania się w danej pozycji [16].
Programowanie postępowania w oparciu o fazy kontroli motorycznej umożliwia płynne przejście od ruchów mających na celu oddziaływanie na struktury i funkcje ciała (np. prawidłowe ustawienie miednicy i odcinka lędźwiowego kręgosłupa u osób ze skoliozą w odcinku lędźwiowym kręgosłupa) do treningu czynności codziennych (np. jedzenie w pozycji siedzącej, wykonywanie czynności domowych w pozycji stojącej, chód).

Terapia osoby ze skoliozą wymaga korekcji położenia kręgosłupa w trzech płaszczyznach. We wszystkich fazach kontroli motorycznej wykorzystuje się trójpłaszczyznowe wzorce ruchowe. Metoda PNF proponuje 8 wzorców ruchowych łopatki i miednicy, 4 wzorce ruchowe odcinka szyjnego i głowy, 16 wzorców ruchowych kończyn górnych, 12 wzorców kończyn dolnych oraz wzorce tułowia. Każdy z wzorców wywołuje aktywność określonych mięśni w łańcuchach mięśniowych [16]. Przykłady wpływu poszczególnych wzorców ruchowych łopatki i miednicy na ustawienie kręgosłupa zamieszczono w Tabeli 1 oraz na Rycinie 1, 2.

Tab. 1. Wzorce łopatki i miednicy - wpływ na aktywność wybranych mięśni i ustawienie kręgosłupa

Tab. 1. Scapula and pelvic patterns - influence on activity of selected muscles and spine alignment

\begin{tabular}{|c|c|c|}
\hline Wzorzec & Mięśnie aktywne & Ustawienie kręgosłupa \\
\hline Elewacja przednia lopatki & $\begin{array}{l}\text { m. dźwigacz łopatki, } \\
\text { m. równoległoboczny, } \\
\text { m. zębaty przedni }\end{array}$ & $\begin{array}{l}\text { zgięcie boczne kręgosłupa - wydłużanie } \\
\text { po stronie wzorca, zwiększenie kifozy } \\
\text { piersiowej, rotacja w kierunku ruchu }\end{array}$ \\
\hline Elewacja tylna łopatki & $\begin{array}{l}\text { m. czworoboczny, } \\
\text { m. dźwigacz łopatki }\end{array}$ & $\begin{array}{l}\text { zgięcie boczne kręgosłupa - wydłużenie } \\
\text { po stronie wzorca, zmniejszenie kifozy } \\
\text { piersiowej, rotacja w kierunku ruchu }\end{array}$ \\
\hline Depresja przednia lopatki & $\begin{array}{l}\text { m. równoległoboczny, } \\
\text { m. zębaty przedni, } \\
\text { m. piersiowy mniejszy i większy }\end{array}$ & $\begin{array}{l}\text { zgięcie boczne kręgosłupa - skrócenie } \\
\text { po stronie wzorca, zwiększenie kifozy } \\
\text { piersiowej, rotacja w kierunku ruchu }\end{array}$ \\
\hline Depresja tylna lopatki & $\begin{array}{l}\text { m. równoległoboczny, } \\
\text { m. zębaty przedni (dolna część), m. } \\
\text { najszerszy grzbietu }\end{array}$ & $\begin{array}{l}\text { zgięcie boczne kręgosłupa - skrócenie } \\
\text { po stronie wzorca, zmniejszenie kifozy } \\
\text { piersiowej, rotacja w kierunku ruchu }\end{array}$ \\
\hline Elewacja przednia miednicy & mm. skośne brzucha & $\begin{array}{l}\text { zgięcie boczne kręgosłupa - skrócenie } \\
\text { po stronie wzorca, zmniejszenie lordozy } \\
\text { lędźwiowej, rotacja w kierunku ruchu }\end{array}$ \\
\hline Elewacja tylna miednicy & $\begin{array}{l}\text { m. czworoboczny lędźwi, } \\
\text { m. najszerszy grzbietu, } \\
\text { m. biodrowo - żebrowy, } \\
\text { m. najdłuższy po tej samej stronie }\end{array}$ & $\begin{array}{l}\text { zgięcie boczne kręgosłupa - skrócenie } \\
\text { po stronie wzorca, zwiększenie lordozy } \\
\text { lędźwiowej, rotacja w kierunku ruchu }\end{array}$ \\
\hline Depresja przednia miednicy & mm. skośne brzucha & $\begin{array}{l}\text { zgięcie boczne kręgosłupa - wydłużenie } \\
\text { po stronie wzorca, zmniejszenie lordozy } \\
\text { lędźwiowej, rotacja w kierunku ruchu }\end{array}$ \\
\hline Depresja tylna miednicy & $\begin{array}{l}\text { m. czworoboczny lędźwi, } \\
\text { m. najszerszy grzbietu, } \\
\text { m. biodrowo - żebrowy, } \\
\text { m. najdłuższy po przeciwnej stronie }\end{array}$ & $\begin{array}{l}\text { zgięcie boczne kręgosłupa - wydłużenie } \\
\text { po stronie wzorca, zwiększenie lordozy } \\
\text { lędźwiowej, rotacja w kierunku ruchu }\end{array}$ \\
\hline
\end{tabular}




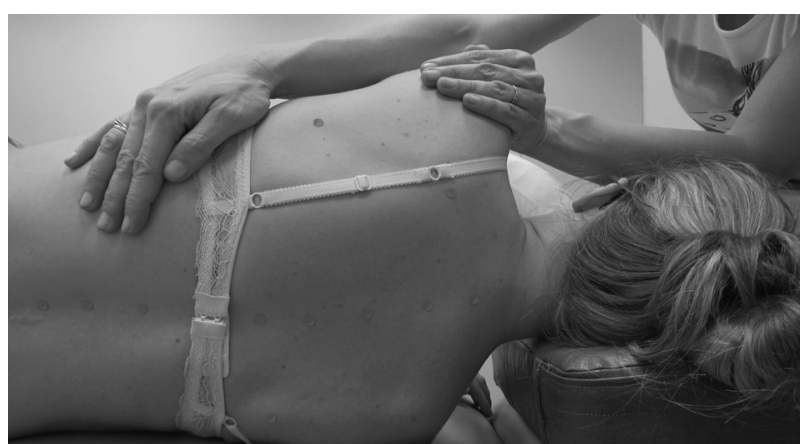

Ryc.1 Elewacja przednia lewej łopatki połączona ze stymulacją oddychania - skolioza dwułukowa (zdjęcie własne)

Fig. 1. Anterior elevation of the left scapula associated with breathing stimulation - double curve scoliosis (own photograph)

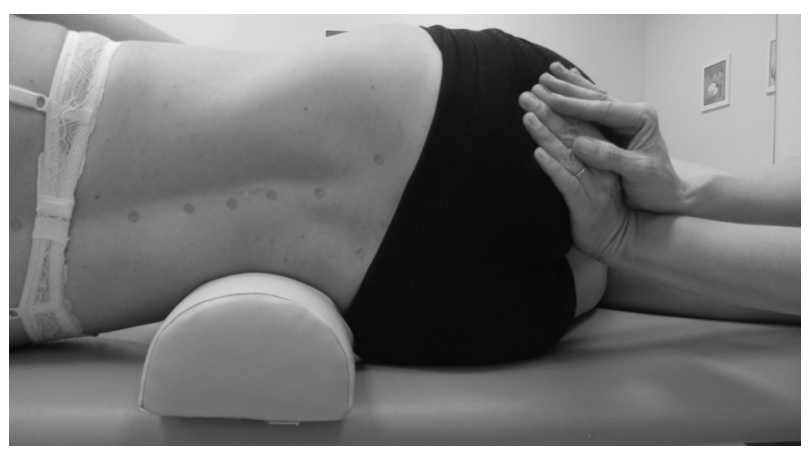

Ryc. 2. Depresja tylna miednicy - skolioza dwułukowa (zdjęcie własne)

Fig. 2. Posterior depression of the pelvis - double curve scoliosis (own photograph)

We wstępnej części terapii, której celem jest uzyskanie korekcji proksymalnych części ciała (mobilność, stabilność) stosuje się więcej wzorców ruchowych łopatek i miednicy, odcinka szyjnego i głowy oraz wzorców kończyn w łańcuchach zamkniętych. Łączenie wzorców ruchowych w różnych pozycjach ciała daje możliwość uzyskania selektywnej przestrzennej korekcji ustawienia kręgosłupa, łopatek, miednicy i kończyn (Ryc. 3). Podczas treningu aktywności dnia codziennego (w fazie mobilność na stabilności, zręczność) oraz treningu chodu wprowadza się stopniowo wzorce kończyn w łańcuchach otwartych z utrzymaniem stabilizacji proksymalnej (tzw. dynamiczna stabilizacja proksymalna). W czasie terapii należy obserwować kompensacje, które pojawiają się w danym odcinku lub w innych częśsiach kręgosłupa.

Członkowie grupy SOSORT dyskutowali w 2005 roku na temat innych celów, które powinny być realizowane podczas leczenia zachowawczego. W dyskusji wskazywano na znaczenie stymulacji czucia głębokiego ułatwiającego rozpoznanie prawidłowego ustawienia ciała w przestrzeni, poprawę neurodynamiki, zwiększenie wytrzymałości mięśni, poprawę reakcji równoważnych i koordynacji ruchowej [6]. Procedury, wzorce, techniki zawarte w metodzie PNF umożliwiają ukierunkowanie oddziaływania na każdą z wymienionych struktur i funkcji ciała.

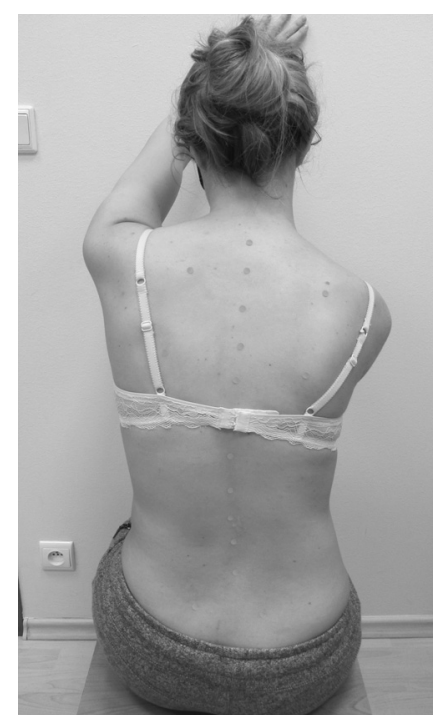

Ryc.3. Korekcja w pozycji siedzącej z wykorzystaniem wzorców ulnar thrust/ lewa kończyna górna i wyprost przywiedzenie rotacja wewnętrzna/ prawa kończyna górna - skolioza dwułukowa (zdjęcie własne)

Fig. 3. Correction in the sitting position - ulnar thrust/ left upper limb and extension, adduction, internal rotation / right upper limb - double curve scoliosis (own photograph)

Do czynników odpowiedzialnych za progresję skoliozy zalicza się między innymi: działanie grawitacji, aktywność mięśni oraz chód [7,25-27]. Z tego właśnie względu terapia powinna być prowadzona w pozycjach wymagających kontroli ciała w warunkach działania grawitacji lub ćwiczeń z dawkowanym oporem zastępującym jej działanie. Wszystkie techniki w metodzie PNF wykonywane są z oporem, a jego wielkość zależna jest od zaplanowanego celu terapii (wzmocnienie mięśni, koordynacja ruchu, rozluźnienie mięśnia). Techniki „Rytmiczne Pobudzanie Ruchu” oraz „Odtwarzanie” dają także możliwość wykonywania ruchów lub przyjęcie prawidłowej pozycji ciała bez oporu manualnego i samodzielnej samooceny wykonanego ruchu, co jest niezwykle ważne dla sprawdzenia efektów nauczania motorycznego.

Wiele badań wykazuje zmianę wzorca chodu u osób z rozpoznaniem skoliozy. Jedną $\mathrm{z}$ zalet metody PNF jest możliwość analizy chodu oraz prowadzenia stymulacji poszczególnych faz chodu. Terapię rozpoczyna się od analizy fazy Mid Stance (MSt). W pozycji stojącej jednonóż zazwyczaj obserwuje się nasilenie asymetrii w ustawieniu tułowia i miednicy. Żadna z proponowanych w chwili obecnej koncepcji fizjoterapeutycznych wykorzystywanych w terapii osób ze skoliozami, poza 
PNF, nie oferuje możliwości poprawy wzorca chodu w poszczególnych fazach.

\section{Dyskusja}

Metoda definiowana jest najczęściej w piśmiennictwie jako ogólny system zasad postępowania i działań w jakiejś dziedzinie, uwzględniający procesy poznawcze i praktyczne ukierunkowane na założony cel oraz kolejność ich zastosowania.

Przez fizjoterapię rozumie się zespół środków leczniczych wykorzystujących zjawisko reaktywności organizmu na bodźce. Zmiany funkcjonowania organizmu pojawiają się dzięki dawkowaniu różnorodnych bodźców. Metody fizjoterapeutyczne obejmują systemy sposobów oddziaływania leczniczego, znajdujące zastosowanie w terapii pacjentów z różnymi rozpoznaniami. Zważywszy na przedstawioną definicję metody, PNF należy uznać za jedną z metod fizjoterapeutycznych, zawierających dokładnie opisane i nazwane sposoby oddziaływania na ciało człowieka w postaci zasad, wzorców ruchowych, technik i faz kontroli motorycznej. Metoda PNF umożliwia dawkowanie różnych bodźców i stymulację wielu receptorów, co ma znaczenie na etapie zmiany/ kształtowania funkcji ciała oraz w procesie nauczania motorycznego.

W pracy wykazano zgodność metody PNF z wytycznymi SOSORT. Jedną z nich jest indywidualne podejście do leczonej osoby. Metoda umożliwia równocześnie realizację podstawowych celów leczenia osób ze skoliozą określonych przez SOSORT: nauczanie umiejętności autokorekcji kręgosłupa i miednicy w trzech płaszczyznach, stabilizację prawidłowej postawy, trening czynności codziennych z uwzględnieniem skorygowanego ustawienia ciała oraz edukację zdrowotną pacjenta i jego rodziny. Dodatkowo metoda PNF proponuje strategię postępowania w postaci faz kontroli motorycznej oraz zasad głównych, które stanowią podstawę do nauczania ruchów i aktywności w każdej pozycji ciała.

SOSORT zaleca stosowanie metod, które zostały poparte badaniami naukowymi. Założenie jest słuszne, ale brak dowodów naukowych na skuteczność jakiejś metody nie oznacza, że metoda ta nie jest skuteczna. Należy zauważyć, że wśród uznanych obecnie metod znajdują się takie, których skuteczność wykazano wiele lat temu, kiedy kryteria oceny prac naukowych były znacznie poniżej obecnych. Wiedza o skuteczności leczenia zachowawczego osób ze skoliozą oraz badania naukowe w tej dziedzinie dopiero się rozwijają. Do chwili obecnej opublikowano stosunkowo niewiele prac na ten temat. Przykładowo w bazie PubMed istnieje 356 publikacji odnoszacych się do metod fizjoterapii stosowanych w leczeniu zachowawczym skolioz, podczas gdy na temat postępowania fizjoterapeutycznego w przebiegu mózgowego porażenia dziecięcego (częstość występowania dziesięciokrotnie mniejsza niż skolioz) powstało ponad 1100 publikacji. W bazie Pedro pod hasłem ,skoliozy metody fizjoterapii” znajdują się zaledwie 3 publikacje, a doniesień na temat metod fizjoterapii stosowanych u osób z porażeniem mózgowym jest 49. Dane te wskazują jednoznacznie, że badania naukowe ukierunkowane na ocenę efektywności działań fizjoterapeutycznych w leczeniu skolioz będą dziełem przyszłości. Wykazanie skuteczności fizjoterapii jest trudnym zadaniem. Wpływa na to wiele czynników. Niektóre ośrodki z racji możliwości zorganizowania pobytu dla pacjentów w warunkach stacjonarnych oraz łączenia fizjoterapii z tym samym typem zaopatrzenia ortopedycznego w postaci gorsetu mają łatwiejsze zadanie. Dużo trudniej jest wykazać skuteczność działań fizjoterapeutycznych w warunkach ambulatoryjnych, w których częstotliwość spotkań jest znacznie mniejsza, a pacjenci często korzystają z innych form terapii i aktywności ruchowej. Często wątpliwa jest też jakość wykonywania zaleceń domowych. Istotną zmienną jest również typ zalecanego gorsetu, odmiennego w różnych ośrodkach w Polsce.

Innym zagadnieniem, o którym należy wspomnieć jest sposób planowania badań naukowych i dowodzenia skuteczności poszczególnych metod fizjoterapii. Metody składają się z systemów oddziaływania złożonych z pojedynczych środków. Czy prace potwierdzające efektywność systemu postępowania $\mathrm{w}$ ramach całej koncepcji wykazują równocześnie skuteczność każdego z zastosowanych środków? Jaki jest zakres indywidualizacji postępowania i zróżnicowania terapii (środków, powtórzeń, czasu terapii) w ramach metody? Czym różni się terapia w zależności od typu skrzywienia w ramach poszczególnych metod?

Metoda PNF posiada szeroki zasób środków oddziaływania na ciało pacjenta, które można łączyć w wybrany sposób. Każdy z ruchów wykorzystywanych w metodzie może stać sie podstawą do przeprowadzenia badań. Czy metoda PNF sprzyja zatrzymaniu progresji skrzywienia w długim okresie czasu? Czy pojedynczy wzorzec ruchowy powtarzany w określonym czasie wywołuje istotne zmiany w ciele osoby ze skoliozą? Trwają badania naukowe ukierunkowane na określenie wpływu działań składających się na metodę PNF oraz ich efektywności. Dotychczas we wstępnych badaniach wykazano, że wybrane wzorce i techniki koncepcji PNF oddziałują pozytywnie na parametry posturalne osób ze skoliozą [28].

\section{Wnioski}

1. Metoda PNF zawiera środki oddziaływania ukierunkowane na realizacje celów określonych przez SOSORT.

2. Metoda PNF jest dokładnie opisana, posiada szczegółową strukturę w postaci nazw zasad głównych, wzorców ruchowych, technik oraz opisu ich wykonania, 
co może być przydatne przy formułowaniu indywidualnych zaleceń dla pacjentów z odmiennymi typami skoliozy oraz planowaniu badań naukowych.

3. Konieczne jest prowadzenie badań mających na celu wykazanie skuteczności metody PNF w procesie leczenia osób ze skoliozą.

\section{Piśmiennictwo:}

1. Grivas TB, Burwell GR, Vasiliadis ES, Webb JK. A segmental radiological study of the spine and rib-cage in children with progressive Infantile Idiopathic Scoliosis. Scoliosis 2006, 1:17.

2. Weinstein SL. Natural history. Spine 1999; 24:2592-2600.

3. Negrini S, Antoninni GI, Carabalona R, Minozzi S. Physical exercises as a treatment for adolescent idiopathic scoliosis. A systematic review. Pediatric Rehabilitation 2003; 6:227235.

4. Weiss HR, Weiss G, Petermann F. Incidence of curvature progression in idiopathic scoliosis patients treated with scoliosis in-patient rehabilitation (SIR): an age- and sex-matched controlled study. Pediatr Rehabil 2003; 6(1):23-30.

5. Romano $\mathrm{M}$ et al. Exercises for adolescent idiopathic scoliosis. Cochrane Database of Systematic Reviews 2009, 2.

6. Weiss HR et al. Indications for conservative management of scoliosis (guidelines) SOSORT guideline committee. Scoliosis 2006, 1:5.

7. Negrini $\mathrm{S}$ et al. 2011 SOSORT guidelines. Orthopaedic and Rehabilitation treatment of idiopathic scoliosis during growth. Scoliosis 2012, 7:3.

8. Ferraro C, Masiero S, Venturin A. Effect of exercise therapy on mild idiopathic scoliosis. Europa Medicophysica 1998; 34: 25-31.

9. Den Boer WA, Anderson PG, v Limbeek J, Kooijman MA. Treatment of idiopathic scoliosis with side-shift therapy: an initial comparison with a brace treatment historical cohort. Eur Spine J 1999; 8(5):406-410.

10. Mamyama T, Kitagawal T, Takeshita K, Nakainura K. Side shift exercise for idiopathic scoliosis after skeletal maturity. Stud Health Technol Inform 2002; 91:361-364.

11. Durmala J, Dobosiewicz K, Kotwicki T, Jendrzejek H. Influence of asymmetric mobilisation of the trunk on the Cobb angle and rotation in idiopathic scoliosisin children and adolescents. Ortop Traumatol Rehab 2003; 5(1):80-85.

12. Otman S, Kose N, Yakut Y. The efficacy of Schroth s 3-dimensional exercise therapy in the treatment of adolescent idiopathic scoliosis in Turkey. Saudi Med J 2005; 26(9):14291435.

13. Lehnert-Schroth C. Dreidimensionale Skoliosebehandlung 6th edition., Urban/Fischer, München; 2000.

14. Negrini S, Negrini A, Romano M, Verzini N, Parzini S. A controlled prospective study on the efficacy of SEAS.02 exercises in preventing progression and bracing in mild idiopathic scoliosis. Stud Health Technol Inform 2006; 123:523-526.
15. Mooney V, Gulick J, Pozos R. A preliminary report on the effect of measured strength training in adolescent idiopathic scoliosis. J Spinal Disord 2000; 13(2):102-107.

16. Adler S, Beckers D, Buck M. PNF in Practice. Springer Verlag Berlin Heidelberg, 2013.

17. Stępień A. PNF - limitations and possibility in pediatric physiotherapy". Congress materials. Annual General Meeting IPNFA, Seoul, Korea, 2013; 35-39.

18. Stępień A. Skolioza nerwowo - mięśniowa - zastosowanie metody PNF z elementami terapii manualnej. Materiały konferencyjne. Sympozjum „Dysfunkcje narządu ruchu u dzieci - zastosowanie metod oraz ich łączenie w kompleksowej rehabilitacji medycznej”. Fundacja Promyk Słońca, Wrocław, 2013; 10-14.

19. ICF. Międzynarodowa Klasyfikacja Funkcjonowania Niepełnosprawności i Zdrowia (ICF 2001). Centrum Systemów Informacyjnych, 2009.

20. Stępień A, Graff K, Podgurniak M. Efekty jednorazowego zastosowania bilateralnych wzorców kończyn dolnych metody PNF i stymulacji asymetrycznego oddychania u dziewcząt ze skoliozą idiopatyczną. Postępy Rehabilitacji, 2014; 3(9): 36.

21. Negrini S, Grivas TB, Kotwicki T, Rigo M, Zaina F. Guidelines on Standards of management of idiopathic scoliosis with corrective braces in everyday clinics and in clinical research. SOSORT Consensus 2008. Scoliosis 2009, 4:2.

22. Weiss $\mathrm{H}$ et al. Physical Exercises in the Treatment of Idiopathic Scoliosis at Risk of brace treatment-SOSORT Consensus paper 2005. Scoliosis 2005.

23. Kotwicki $\mathrm{T}$ et al. Methodology of evaluation of morphology of the spine and the trunk in idiopathic scoliosis and other spinal deformities -6 th SOSORT consensus paper Scoliosis 2009; 4:26.

24. Romano M, Negrini S. Manual therapy as a conservative treatment for adolescent idiopathic scoliosis: a systematic review. Scoliosis 2008, 3:2.

25. Stępień A, Seyfried A, Krawczyk M, Graff K. Wpływ deformacji kręgosłupa na sposób obciążania stóp w czasie chodu u osób ze skoliozą idiopatyczną. Postępy Rehabilitacji 2007; 2: 13-20.

26. Syczewska M, Graff K, Łukaszewska A, Górak B. Gait pat tern of children with scoliosis. 1-st Joint ESMAC - GCMAS Meeting. Amsterdam 2006.

27. Syczewska M, Graff K, Kalinowska M, Szczerbik E, Domaniecki J. Influence of the structural deformity of the spine on the gait pathology in scoliotic patients. Gait \& Posture 2012; 12 (2), 209-213.

28. Stępień A, Graff K, Podgurniak M. A short - time effect of one- session application of Proprioceptive Neuromuscular Facilitation (PNF) bilateral leg pattern used with Contract Relax technique and asymmetrical breathing in girls with adolescent idiopathic scoliosis (AIS).The International Congress on Scoliosis Orthopaedic and Rehabilitation Treatment, Congress Materials, 2014, 74, OPOS2/018. 